\title{
КОРОНАВІРУС ЯК ПРЕЦЕДЕНТНА ОДИНИЦЯ В СУЧАСНОМУ ІНФОРМАЦІЙНОМУ ПРОСТОРІ
}

У пропонованій статті розглянуто процес появи нової прецедентної одинииі; спостерігаємо динаміку розвитку ії семантики, набуття нею нового глибинного значення та вплив прецедентної одинииі «коронавірус» на розвиток української мови. Висновкуємо, щзо прецедентна одиниия пройшла трансбормацію, перетворивщись з назви хвороби на прецедентну назву, яка відома широкому загалу й несе в собі унікальний код, щзо створює взаємозв'язок між адресатом і адресантом. Набувши статусу прецедентної, ия тексична одиниия успішно стала базою для утворення нових лексем, чим поповнює словниковий склад української мови.

Ключові слова: прецедент, прецедентна одиниия, прецедентна назва, лексична одиниия, коронавірус, глибинне значення.

Yukhno Ye. Coronavirus as a Precedent Unit in the Modern Informational Space. Precedent is widely represented in the media and publicistic space. It is a kind of unique code that reduces the distance between the author and the reader, facilitates the perception of information, pushes the chosen course of thought and storms the subconscious. Despite the popularity of the topic, the modern development of linguistic science, the term "precedent phenomenon» still has no common interpretation.

The proposed article considers the process of appearance of a new precedent unit, the dynamics of its development, its acquisition of deep significance and the impact on the development of the Ukrainian language. We conclude that the precedent unit has undergone a transformation, turning from the name of the disease into a precedent name known to the general public. The precedent unit of the coronavirus has undergone a systematic transformation from the name of the disease to the precedent name of a wide geographical distribution. It contains social, national, international and universal levels. The dynamic development of the phenomenon and, accordingly, its reflection in the language, made the emergence of a new precedent unit possible, which is successfully played out in modern journalistic discourse. This attracts the reader's attention, forms a new code of communication and reduces the distance between the reader and the author. Having acquired precedent value, this unit of language successfully replenishes the vocabulary of the Ukrainian language, forming new tokens.

The wide range of precedents in journalism explains the fragmentary nature of scientific research and needs for further study, in particular, we see a more in-depth study of metaphorical models of the use of the precedent name coronavirus in modern mass media and journalistic speech.

Keywords: precedent, precedent unit, precedent name, coronavirus, deep meaning. 


\section{Вступ}

Як відомо, публіцистична реальність створюється тим, що сказане або написане фіксують та інтерпретують у вигляді текстів і розмов. Публіцистична діяльність передовсім є мовленнєвою, бо складається зі словесних дій у супроводі паравербальних і невербальних явищ. Діяльність кожного публічного діяча зумовлена впливом реальності й передбачає використання відповідних лексем, зокрема неологізмів. Інший спосіб мовленнєвої діяльності публіцистів полягає у використанні стійких та впізнаваних концептів, що скорочують дистанцію сприйняття коду (Яворська, 2012: 226).

Вивчення теорії феномену прецедентності перебуває у фокусі активних наукових досліджень упродовж декількох останніх десятиліть. Цією проблемою займалися такі корифеї лінгвістичної доктрини, як Ю. А. Сорокін, Д. Б. Гудков, В. В. Красних, О. О. Селіванова, Ю. Крістєва, A. Goddard та ін. В україністиці їй приділяють увагу сучасні вчені-лінгвісти Ю. М. Великорода, Н. В. Піддубна, А. А. Берестова, О. А. Ільченко, Р. С. Чорновол-Ткаченко та ін.

Найчастіше прецедентні феномени вживають у політичному та медійному дискурсах. За спостереженням науковців, найбільш використовуваними ж є дві сфери-джерела: політика та література (Берестова, 2016: 23).

Попри наявність багатьох досліджень проблеми прецедентності, ми досі не маємо єдиного визначення цього поняття, на що, зокрема, вказує М. Ю. Великорода (Великорода, 2012: 12). Ж. В. Колоїз у праці «Словник прецедентних феноменів» також наголошує, що на сучасному етапі розвитку лінгвістичної науки термін «прецедентгий феномен» досі немає загальноприйнятого потрактування (Колоїз, 2017).

У дискусійній формі Ю. А. Сорокін, Д. Б. Гудков і В. В.Красних наголошують на існуванні прецедентності як терміна, визначаючи його критерії й виділяючи такі властивості феномена прецедентності, як, по-перше, повторюваність, по-друге, маркування, усередині якого виникає слабке й сильне маркування, що сприяє появі третьої властивості, а саме відрефлексування. Названі умовні властивості прецедента спричиняються до появи різних прецедентних рівнів автопрецеденти, соціумні прецеденти, національні й універсальні прецеденти (Красных, 1997: 6). 
О. А. Ільченко зазначає, що прецедентність - це важлива ознака текстів сучасної преси, що спирається на фонові знання читача й інтуїцію автора-журналіста. У такий спосіб актуалізується необхідна інформація й відповідно інтерпретується - відбувається інтелектуальний діалог адресанта й адресата (Ільченко, 2012: 100).

А. А. Берестова, спираючись на дослідження попередників, указує на те, що «прецедентний феномен - це ядерний елемент когнітивної бази певної лінгвокультурної спільноти, який має здатність у стислій формі зберігати інформацію про взірцеві факти й виступає моделлю для відтворення подібних фактів, репрезентований і постійно поновлюваний у мовленні за допомогою відповідних вербальних сигналів, що актуалізують його стандартний (відомий усім представникам цієї лінгвокультурної спільноти) зміст» (Берестова, 2016: 12).

Система прецедентів є досить рухливою. На конкретному мовному матеріалі (газети, телебачення) бачимо динаміку появи нових прецедентних одиниць. Метою нашої статті є дослідити функціювання прецедентної лексеми коронавірус у сучасному мас-медійному просторі, для чого поставили такі завдання: 1) схарактеризувати динаміку вживання зазначеної прецедентної одиниці в публіцистичному дискурсі 2020 року; 2) визначити особливості використання лексеми коронавірус у заголовкових позиціях сучасних мас-медіа.

\section{Методи дослідження}

У процесі дослідження було застосовано такі методи: концептуально-аналітичний, що сприяв методологічній оцінці теоретичних положень терміна прецедентність; для аналізу матеріалу використано описовий метод, контекстуально-інтерпретаційний, дискурсивний, комунікативно-прагматичний та лексико-синтаксичний методи аналізу, що дали змогу співвіднести текстові / дискурсивні явища з низкою екстралінгвальних чинників, спроєктованих на тлумачення публіцистичного тексту. Залучення компонентного та трансбормациійного аналізів сприяло виявленню семантичних складників у досліджуваних мовних одиницях.

\section{Виклад основного матеріалу}

Оскільки сама хвороба, номінована лексемою коронавірус, була безпрецедентним явищем, то, відповідно, і ії назва вживалася вкрай рідко й була надбанням галузевої, зокрема медичної, термінології, 
порівн.: Міжнародний комітет із систематики вірусів (International Committee on Taxonomy of Viruses (ICTV)) додав у перелік назв термінів хвороб коноравірус уперше у 1971 році, використовуючи латинську назву coronaviridae, який пізніше (1975 рік) трансформувався у coronavirus [міжнародний комітет таксономії вірусів]. Тобто сучасна назва вірусу є абсолютною транслітерацією з латинської мови. На безпрецедентності цього явища в нашому житті наголошено у пості Facebook Президента України В. О. Зеленського 20 лютого 2020 року: «Заходи безпеки і вірус - безпрецедентні» [офіційна сторінка Президента України в соцмережі Facebook; газета «День», випуск № 30, 2020]. Однак уже за кілька тижнів, як свідчать заголовки українських газет, лексична одиниця коронавірус набує нового, а саме прецедентного, характеру та виходить на національний рівень прецедентності, адже проновані українському народу назви заголовків мають більш глибокий характер і поєднані з ним конотації, напр.: «Беремо своїх, за великі гроші: як загроза коронавірусу показує справжне обличчя глитаїв-бізнесменів» [газета «Україна молода», випуск № 029 за 17.03.2020], «Тест на людяність: на часі безкорислива допомога y боротьбі з коронавірусом» [газета «Україна молода», випуск № 029 за 18.03.2020].

Фактично одразу прецедентна назва коронавірус збагачується синонімами, зокрема перифразами, напр.: «Вірус із короною: ситуація в Україні та світі» [канал «Ранок з “Інтером"», 26.02.2020].

Заголовки американських, англійських, італійських та ін. часописів свідчать про рухливість прецедентної назви. Тобто ії національний статує стає вже інтернаціональним і навіть універсальним, тому що охоплює соціальну, релігійну, політичну, економічну та інші сфери поширення: «How coronavirus will change the world forever»[газета «Times»], "Johannesburg Covid-19 crisis: 'The storm is upon us» [газета «FinancialTimes»], «Coronavirus, la pandemia che ha spaventato il mondo» [газета «Il Messaggero»].

Відповідно до цього вживання прецедентної назви коронавірус та іiі похідних можна кваліфікувати як таку, що має 1) поверхневе значення, що дорівнює сумі значень компонентів висловлювання: «У Литві оголосили надзвичайний стан через коронавірус» [газета «Україна молода», випуск № 023 за 28.02.2020], «У Гонконзі собаку помістили на карантин після позитивного аналізу на коронавірус»[газета 
«Україна молода», випуск № 023 за 28.02.2020]; 2) глибинне значення, яке не дорівнює простій сумі значень компонентів висловлювання, але $є$ семантичним результатом поєднання компонентів, які формують його лексико-граматичну структуру, напр.:«Коронавірусна наука: як карантин ускладнив випускникам складання ЗНО» [газета «Україна молода», випуск № 062 за 14.07.2020], «Коронавірус популізму» [газета «День», випуск № 35, 2020]; 3) системне значення, що $\epsilon$ “сумою” глибинного значення висловлювання і знання прецедентного феномену та пов’язаних з ним конотацій, напр.:«Коронавірус не лише хворобою давить людей, а й рентгеном серия душі просвічує» ${ }^{1}$.

У зв'язку з різноманітністю форми й семантики прецедентного феномену така класифікація є актуальною для будь-якого вияву прецедентності в мовленні (Красных, 1998: 96).

Динаміку вживання нової прецедентної лексеми вбачаємо й у появі утворених на її основі нових слів, наприклад, новотвору-оказіоналізму коронапереворот, у якому два твірних слова корона й переворот повністю перенесли свою семантику в утворення нового композита зі збереженням всієї граматичної структури, але при цьому передається новий зміст: "Державний коронапереворот: мертва блокада громадських свобод украӥнців» [газета «Україна молода», випуск № 032 за 10.04.2020].

У зв’язку з різноманітністю форми й семантики прецедентного феномену такий розподіл $є$ актуальним для будь-якого вияву прецедентності в мовленні (Красных, 1998: 96).

Дуже швидко в заголовках як сильних текстових позиціях починають виявлятися нові смисли лексеми коронавірус і похідних, напр.: «Скандальна «коронація» Полякової: кого посадять за кониерт?» [телеканал «Україна24», 10.10.2020]. Загальновідома співачка Оля Полякова, що вже кілька років поспіль називає себе королевою, стає головною героїнею провокативного випуску, де йдеться про неї не як про королеву естради, а висуваються звинувачення в сприянні розповсюдження коронавірусу. Тобто в цьому заголовку відбувається мовна гра, яка інтригує читача й підсилює його інтерес до випуску.

Наступні приклади не лише демонструють прецедентність

${ }^{1}$ Яровий В. Коронавірус не лише хворобою давить людей, а й рентгеном серця душі просвічує. Zemlyaivolya.net: портал академії успіху Узято з http://www.zemlyaivolya.net/articles/ koronavirus_ne_lishe_hvoroboyu_davit_lyudey_rentge.html. 
лексеми коронавірус, а й унаочнюють ії активне залучення до мовної гри, надаючи їй тим самим ознак живого мовлення, водночас полегшуючи читачам сприйняття й актуалізуючи нові приховані смисли, напр.: «Хто породив коронавірус? Докази «батьківства» Китаю побачили «П’ятеро очей» [газета «Україна молода», випуск № 038 за 05.05.2020]. У назві цієї статті наявна персоніфікація, тобто коронавірусу надано ознаки живого. Риторичне питання «Хто породив?» відсилає читача до іншого прецедентного вислову з повісті М. В. Гоголя «Тарас Бульба», а саме до слів головного героя «Я тебе породив, я тебе і вб'ю», посилюючи мовну гру. Зауважимо, що така своєрідна контамінація прецедентних одиниць є типовою для сучасних газетних заголовків, як-от: “Коронавірус як дзеркало Російської держави» [газета «День», випуск № 49, 2020]. Назва цієї статті не лише метафорична, у ній також виявляється мовна гра, загрунтована на трансформації назви статті В. І. Леніна «Лев Толстой как зеркало русской революиии» [Пролетарий, 1908, 11(24) сентября, № 35]. Часто такі назви використовують представники певної лінгвокультурної спільноти, зокрема представники пострадянського простору. Тобто прецедентну одиницю використовують у трансформованому прецедентному вислові, що, з одного боку, більш заплутує читача, а з другого, - відразу скеровує в потрібне русло інформаційного потоку й змушує згадувати історичний досвід своєї країни.

\section{Висновки}

Отже, можемо констатувати, що прецедентна одиниця коронавірус пройшла системну трансформацію від назви хвороби до універсальної прецедентної назви. Динамічний розвиток явища й, відповідно, відбиття його в мові - уможливили появу нової прецедентної одиниці, що ії вдало використовують у сучасному публіцистичному дискурсі, зокрема в процесі залучення - до мовної гри. Це привертає увагу читача, формує новий код спілкування, скорочує дистанцію між читачем та автором.

Широкий спектр прояву прецедентності в публіцистиці пояснює фрагментарність наукових досліджень і потребує подальшого вивчення, зокрема перспективним убачаємо більш глибоке дослідження метафоричних моделей уживання прецедентної назви коронавірус у сучасному мас-медійному й публіцистичному мовленні, а також з’ясування механізмів залучення досліджуваної одиниці до мовної гри. 


\section{ЛІТЕРАТУРА}

1. Берестова, А. А. (2016). Релігійна прецедентність у мові української прози кінця XX - початку XXI століття. (Дис. ... канд. філол. наук). Харків: ХНПУ імені Г. С. Сковороди. 2. Бурвикова, Н. Д. (2006) Жизнь в мимолетных мелочах. СПб.: Златоуст. 3. Великорода, Ю. М. (2012) Прецедентні феномени в американському медійному дискурсі (на матеріалі часописів «TIME» і «NEWSWEEK»). (Дис. ... канд. філол. наук). Львів: Львів. нац. ун-т ім. Івана Франка. 4. Власова, Т. М., Дюжева, М. Б. (2013). Актуализация прецедентности в журнальном дискурсе (на материале заголовков статей русского издания «ROLLINGSTONE»). Гуманитарные исследования в Сибири и на Дальнем Востоке, 6, 146-152. 5. Гудков, Д. Б. (2003) Теория и практика межкультурной коммуникации. Москва: Гнозис. 6. Екологія мови і мовна політика в сучасному суспільстві: зб. наук. пр. (2012). Київ: Вид. дім Дм. Бураго. 7. Загнітко, А. (2012) Словник сучасної лінгвістики : поняття і терміни. Донецьк: ДонНУ. 8. Земская, Е. А. (1996) Еще раз о языке русского зарубежья. Язык - система. Язык - текст. Языкспособность. Москва: Ин-т рус. яз. им. В. В. Виноградова. 9. Ільченко, О. А. (2012) Прецедентність як ознака текстів сучасної преси (на матеріалі метафоричних словосполучень). Лінгвістичні дослідження, 34, 97-100. 10. Колоїз, Ж. В. (2017). Проект українського «Словника прецедентних феноменів». Філологічні студіi. Наук. вісн. Кривор. держ. пед. ун-ту, 16, 139-160. 11. Красных, В. В. (Ред.) (1997) Язык, сознание, коммуникация, 1. Москва: Филология. 12. Красных, В. В. (Ред.) (1998) Язык, сознание, коммуникация, 4. Москва: Филология. 13. Нагорна, Л. П. (2005) Політична мова і мовна політика: діапазон можливостей політичної лінгвістики. Київ: Світогляд.

\section{REFERENCES}

1. Berestova, A. A. (2016) Relihiina pretsedentnist u movi ukrainskoi prozy kintsia $\mathrm{XX}$ - pochatku KhKhI stolittia [Religious precedent in the language of Ukrainian prose of the late XX - early XXI century]. Candidate's thesis. Kharkiv: KhNPU imeni H. S. Skovorody [in Ukranian]. 2. Burvykova, N. D. (2006) Zhyzn v mymoletnykh melochakh [Life in fleeting trifles]. SPb.: Zlatoust.[in Russian]. 3. Velykoroda, Yu. M. (2012) Pretsedentni fenomeny v amerykanskomu mediinomu dyskursi (na materiali chasopysiv «TIME» $\mathrm{i}$ «NEWSWEEK») [Precedent phenomena in American media discourse (based on TIME and NEWSWEEK magazines)]. Candidate's thesis. Lviv: Lviv nats. un-t im. Ivana Franka [in Ukranian]. 4. Vlasova, T. M., Diuzheva, M. B. (2013). Aktualyzatsyia pretsedentnosty v zhurnalnom dyskurse (na materyale zaholovkov statei russkoho yzdanyia «ROLLING STONE») [Actualization of precedent in journal discourse (based on the titles of articles in the Russian edition of «ROLLING STONE»)]. Humanytarnble yssledovanye v Sybyre y na Dalnem Vostoke - Humanities research in Siberia and the Far East, 6, 146-152 [in Russian]. 5. Hudkov, D. B. (2003) Teoryia y praktyka mezhkulturnoi kommunykatsyy [Theory and practice of intercultural communication]. Moskva: Hnozys [in Russian]. 6. Ekolohiia movy i movna polityka v suchasnomu suspilstvi (2012) [Ecology of language and language policy in modern society]. Kyiv: Vyd. dim Dm. Buraho [in Ukranian]. 7. Zahnitko, A. (2012) Slovnyk suchasnoi linhvistyky : poniattia iterminy [Dictionary of modern linguistics: concepts and terms]. Donetsk: DonNU [in Ukranian]. 8. Zemskaia, E. A. (1996) Eshche raz o yazyke russkoho zarubezhia. Yazyk - systema. Yazyk - tekst. Yazyk - sposobnost [Once again about the language of Russian abroad. Language is a system. Language is text. Language is 
an ability]. Moskva: In-t rus. yaz. ym. V. V. Vynohradova [in Russian]. 9. Ilchenko, O. A. (2012). Pretsedentnist yak oznaka tekstiv suchasnoi presy (na materiali metaforychnykh slovospoluchen) [Precedent as a feature of modern press texts (based on metaphorical phrases)]. Linhvistychni doslidzhennia - Linguistic research, 34, 97-100 [in Ukranian]. 10. Koloiz, Zh. V. (2017). Proekt ukrainskoho «Slovnyka pretsedentnykh fenomeniv» [Project of the Ukrainian «Dictionary of precedent phenomena»]. Filolohichni studii. Nauk. visn. Kryvor. derzh. ped. un-tu - Philological studies. Scientific Bulletin of Kryvyi Rih State Pedagogical University, 16, 139-160 [in Ukranian]. 11. Krasnykh, V. V. (Red.) (1997) Yazyk, soznanye, kommunykatsyia [Language, consciousness, communication], 1. Moskva: Fylolohyia [in Russian] 12. Krasnykh, V. V. (Red.) (1998) Yazyk, soznanye, kommunykatsyia [Language, consciousness, communication], 4. Moskva: Fylolohyia [in Russian]. 13. Nahorna, L. P. (2005) Politychna mova i movna polityka: diapazon mozhlyvostei politychnoi linhvistyky [Political language and language policy: the range of possibilities of political linguistics]. Kyiv: Svitohliad [in Ukranian].

Юхно Євгенія Володимирівна - аспірантка кафедри української мови, Харківський національний педагогічний університет імені Г. С. Сковороди; вул. Валентинівська, 2, м. Харків, 61168, Україна.

Tel.: +38-068-080-52-58

E-mail: yevheniiayukhnii@gmail.com

https://orcid.org/0000-0002-8000-9851

Yukhno Yevheniia Volodymyrivna - Postgraduate Student at the Department of Ukrainian Language, H. S. Skovoroda Kharkiv National Pedagogical University; Valentynivska Str. 2, Kharkiv, 61168, Ukraine.

Надійшла до редакції 20 вересня 2020 року

\section{CITATION}

ДСТУ 8302:2015: Юхно Є. В. Коронавірус як прецедентна одиниця в сучасному інформаційному просторі. Лінгвістичні дослідження: зб. наук. пр. Харк. нац. пед. унту імені Г. С. Сковороди. Харків, 2020. Вип. 53. С. 55-62. DOI: https://doi.org/10.34142/ 23127546.2020.53.05

APA: Юхно, Є. В. (2020). Коронавірус як прецедентна одиниця в сучасному інформаційному просторі. Лінгвістичні дослідження, 53, 55-62. DOI: https://oi.org/ $10.34142 / 23127546.2020 .53 .05$ 